\title{
Assessment of the Ecological and Economical Trends for Mining Region (on Example of Kuzbass)
}

\author{
Ludmila Starikova ${ }^{1, *}$, and Irina Trapeznikova ${ }^{2}$ \\ ${ }^{1}$ Russian Economic University named after G.V. Plekhanov, Kemerovo Institute, 650025 Kuznetskiy \\ pr-t 39, Kemerovo, Russia \\ ${ }^{2}$ Kemerovo State University, 650000, Krasnaya str 6, Kemerovo, Russia
}

\begin{abstract}
In the modern scientific literature, a number of methods have been developed making it possible to assess the ecological state of the territory. The most common way is to estimate the gross inflow of pollutants into various objects of the natural environment. The typology of the territory according to the level of the technogenic loading is considered for all environment: water, air and surface. As indicators, the density of emissions of harmful substances into the atmosphere per $1 \mathrm{~km}^{2}$ and density of discharge of pollutants into water sources with wastewater through organized releases per 1 million $\mathrm{m}^{3}$ of monthly flow are taken. As indicators of environmental intensity were considered indicators of energy intensity, material intensity, water capacity, metal intensity, specific emissions of greenhouse gases.
\end{abstract}

\section{Introduction}

As a baseline, it is permissible to take the level of pollution of air, water basins and soil cover as exceeding the permissible level of Maximum Allowable Concentration (further MAC). At the same time, four qualitative levels of the state of the surrounding natural environment are distinguished:

- the zone of catastrophically high pollution is characterized by the fact that the average annual concentrations for several or one specific pollutant in different environments will exceed 5 MAC (by specific pollutants we mean pollutants not inherent in the combustion products of fuel: ash, sulphurous gas, nitrogen dioxide, carbon monoxide). these substances are considered to be the main impurities. in such a zone the ecological balance in the environment is violated and the natural potential of self-cleaning can not cope with the available loads;

- the second zone is a zone with a high level of contamination. for the areas caught in this zone, the contamination of the media with at least one impurity in the range of 2-5 MAC or several, including specific impurities within 1-2 MAC, is typical. in these zones, especially during periods of unfavorable meteorological conditions, the ecological situation deteriorates sharply, but no changes in any parts of the ecosystem are observed;

\footnotetext{
*Corresponding author: $\underline{\ln 550 \text { list.ru }}$
} 
- the third zone is a zone of moderate pollution. The areas that fall into this zone are characterized mainly by contamination with combustion products of fuel with concentrations of 1-2 MAC.

- the fourth zone with a low level of pollution. The areas that fall into this zone can be considered relatively clean, although episodically the concentrations of harmful impurities can rise to the MAC [1].

\section{Materials and Methods}

In this work, we divided the territory of Kuzbass (Kemerovo region, Western Siberia, Russia) into a number of regions according to the homogeneity of landscape and geographical conditions and technogenic loads (Table 1).

Table 1. Ecological and economical zoning of Kemerovo Region.

\begin{tabular}{|l|c|c|c|c|}
\hline \multicolumn{1}{|c|}{ Indicators } & \multicolumn{3}{|c|}{ Ecological and economical zone } \\
\cline { 2 - 5 } & Northern & Central & $\begin{array}{l}\text { South- } \\
\text { Western }\end{array}$ & Southern \\
\hline Number of administrative districts & 8 & 7 & 3 & 2 \\
\hline$\%$ to the area of the region & 30 & 42 & 16 & 11 \\
\hline $\begin{array}{l}\text { Specific weight of non-agricultural } \\
\text { land,\% of total area }\end{array}$ & 4 & 18 & 22 & 6 \\
\hline $\begin{array}{l}\text { The prevailing type of using of the } \\
\text { territory }\end{array}$ & Agricultural & Industrial & Industrial & Recreational \\
\hline $\begin{array}{l}\text { Density of emissions of harmful } \\
\text { substances into the atmosphere per } \\
1 \text { km }\end{array}$ & 5 & 27 & 32 & 1,2 \\
\hline $\begin{array}{l}\text { Density of discharge of pollutants } \\
\text { into water sources with sewage } \\
\text { through organized releases per 1 } \\
\text { million m3 of monthly flow }\end{array}$ & 30 & 151 & 112 & 11 \\
\hline
\end{tabular}

The first group is the territory subjected to a very strong man-made impact on virtually all constituent elements of the environment, namely: the destruction and degradation of the soil cover, the disturbance of the hydrological regime and the contamination of groundwater and surface water, pollution of the atmosphere by industrial emissions, and degradation of natural flora and fauna. These territories belong to the Central and SouthWest eco-geographical regions. The boundaries of the maximum technogenic "press" on the biosphere coincide with the boundaries of these areas. This is approximately $30 \%$ of the territory within the administrative boundary of the Kemerovo region, where about $65-70 \%$ of the population lives. Pollution is distributed evenly throughout the Central District. The area is characterized by a strong disturbance of the fertile soil layer, primarily in places of open and underground coal mining, and also due to the high rate of plowing (up to $70 \%$ ). In addition, the peculiarity of this territory, the constant pollution of flood plain soils with industrial effluents and waste from livestock farms. The south-western region includes Prokopyevsk and Novokuznetsk districts. Here pollution zones of Novokuznetsk, Kiselevsk and Prokopyevsk are overlapped. The inhabited parts, located in the south-western zone, have a double, and sometimes triple, background from the pollution of the atmosphere. Roses of the emissions of nearby cities are superimposed on each other. The district is the center of the metallurgical industry of the region, in addition, there are South Kuzbass state district power station, Tom-Usinskaya state district power station and more than 40 coalmining and coal-processing enterprises. Pollution is catastrophically high for all environmental objects. The state of rivers flowing through the territory of the district is 
estimated as 5-4 grade, dirty - contaminated. The districts of the cities of Prokopyevsk and Kiselevsk are characterized by a high violation of natural landscapes. The total area of disturbed land in the area reaches 20 thousand hectares. A characteristic feature - a huge amount of production and consumption waste, placed annually in the described territory $21 \%$ of the land only in the Prokopyevsk area is used for waste. In the vicinity of Mezhdurechensk, the area of disturbed lands with open coal mining is 10.5 thousand hectares. A kind of "post industrial desert" was formed with adverse environmental conditions - dusty atmosphere, the desiccation of surface layers of air, high temperatures in the summer.

The second group - the Northern region - (about $40 \%$ of the territory, 20-25\% of the population) suffers a sufficiently high man-made load from their own enterprises and through the transfer of pollution from neighboring territories, but high forest cover largely stabilizes the ecological situation. The northern zone is characterized by a satisfactory state of the surrounding natural environment, and only the western part is under the influence of the Kemerovo industrial hub. On the territory of this region large, almost untouched natural massifs are located (especially on the northern border). The main ecological problem of the area is soil contamination in the Tisulsky and Tyazhinsky Districts-agriculture is quite developed in this zone, and the soil cover is universally disturbed by agrotechnical measures.

And, finally, the third group of ecogeographical regions (approximately $30 \%$ of the region, where $5-10 \%$ of the population live) are classified as ecologically satisfactory. This includes the south-east and the extreme southern region - Mezhdurechensky (with the exception of Mezhdurechensk) and Tashtagolsky districts. $60 \%$ of this territory is occupied by almost untouched natural massifs. It should be noted that all the territories of the third group of ecological and geographical areas are located outside the boundaries of the Kuznetsk coal basin.

As separate indicators of environmental intensity at the macro level for GRP, one can consider indicators of energy intensity, material intensity, water capacity, metal intensity, specific greenhouse gas emissions. Also, modified nature intensity indicators are used, based on the total population of the region: the costs of natural resources or the amount of pollution per capita or per unit area.

Reducing of the environmental intensity of the economy is one of the necessary conditions for the transition to sustainable economic development. There can be no movement along the trajectory of sustainable development with increasing use of natural resources and pollution per unit of final result (Table 2).

Table 2. Natural capacity manufactured industrial products, in dynamics, $2003-2016$ [2], (for example, emissions into the atmosphere $\mathrm{SOX}$ and $\mathrm{CO} 2$ ).

\begin{tabular}{|c|c|c|c|c|c|c|}
\hline Regions & \multicolumn{2}{|c|}{$\begin{array}{c}\text { Energy intensity of } \\
\text { manufactured } \\
\text { industrial output } \\
\text { (tone of oil } \\
\text { equivalent / thousand } \\
\text { US dollars) }\end{array}$} & \multicolumn{2}{|c|}{$\begin{array}{c}\text { Emissions of, SOx } \\
\text { tons / thous. dol. US }\end{array}$} & \multicolumn{2}{|c|}{$\begin{array}{c}\text { Emissions of CO2, } \\
\text { tons / thousand USD } \\
\text { US }\end{array}$} \\
\hline & 2003 & 2016 & 2003 & 2016 & 2003 & 2016 \\
\hline Japan & 0.17 & 0.16 & 0.3 & 0.26 & 0.42 & 0.4 \\
\hline Germany & 0.21 & 0.16 & 1.1 & 0.8 & 0.52 & 0.4 \\
\hline USA & 0.28 & 0.22 & 2.1 & 1.6 & 0.72 & 0.6 \\
\hline Russia & 0.61 & 0.5 & 6 & 5.2 & 1.54 & 1.2 \\
\hline
\end{tabular}




\begin{tabular}{|c|c|c|c|c|c|c|}
\hline Regions & \multicolumn{2}{|c|}{$\begin{array}{c}\text { Energy intensity of } \\
\text { manufactured } \\
\text { industrial output } \\
\text { (tone of oil } \\
\text { equivalent / thousand } \\
\text { US dollars) }\end{array}$} & \multicolumn{2}{|c|}{$\begin{array}{l}\text { Emissions of , SOx } \\
\text { tons / thous. dol. US }\end{array}$} & \multicolumn{2}{|c|}{$\begin{array}{c}\text { Emissions of CO2, } \\
\text { tons / thousand USD } \\
\text { US }\end{array}$} \\
\hline $\begin{array}{l}\text { Kemerovo } \\
\text { region }\end{array}$ & 0.48 & 0.4 & 3.6 & 3.0 & 4.82 & 3.9 \\
\hline
\end{tabular}

Comparison of the nature intensities shown in Table 2 gives indicative results. Energy costs (energy intensity) per unit of final output in Russia in comparison with developed countries is 2-3 times more. For Kemerovo region, this indicator is also quite high, and although it is lower than the Russian one, it nevertheless exceeds the energy intensity of Japan and European countries.

Interregional comparisons of the gross regional product(GRP) energy intensity show (Table 3) that in terms of electricity consumption in the Siberian Federal District, the Kemerovo Region ranks third, behind the Republic of Khakassia and Irkutsk region.

In terms of consumption of heat and boiler-furnace fuel, the region is on the first place, leading with the second indicator with an undeniable margin (Table 3).

There is an extremely large gap in the indicators of the nature of the developed countries and Russia for air pollutants. Thus, the specific emissions of sulfur oxides, which lead to acid rains and the degradation of large areas of forests and lands, are 20 times higher in the country than in Japan and Norway, and approximately 6-7 times higher than in Germany and France. In the Kemerovo region, this figure exceeds the Japanese one by 12 times, and by 3 times are the indicators of the countries of Western Europe.

The produced carbon dioxide, the main greenhouse gas, leading to global climate change, exceeds the indicators of developed countries per unit of gross output by 3-4 times in Russia. In Kemerovo region, the total emission of carbon dioxide is 3.12 times higher than the Russian one.

Table 3. Energy intensity of gross regional product, 2014-2015 [3].

\begin{tabular}{|l|c|c|}
\hline \multicolumn{2}{|c|}{ Consumption of energy resources kg of conventional fuel / 10 thousand rubles } \\
\hline \multicolumn{1}{|c|}{ Siberian Federal District } & $\mathbf{2 0 1 4}$ & $\mathbf{2 0 1 5}$ \\
\hline Altai Republic & 142.74 & 130.48 \\
\hline The Republic of Buryatia & 186.36 & 173.65 \\
\hline Tyva Republic & 350.00 & 373.43 \\
\hline The Republic of Khakassia & 409.29 & 369.85 \\
\hline Altai Region & 226.28 & 192.56 \\
\hline \multicolumn{1}{|c|}{ Transbaikal Region } & 195.80 & 177.90 \\
\hline Krasnoyarsk Region & 201.21 & 179.39 \\
\hline Irkutsk Region & 338.50 & 252.41 \\
\hline Kemerovo Region & $\mathbf{5 4 2 . 0 2}$ & $\mathbf{4 4 9 . 6 2}$ \\
\hline Novosibirsk Region & 123.41 & 108.61 \\
\hline Omsk Region & 177.46 & 162.84 \\
\hline Tomsk Region & 129.09 & 114.22 \\
\hline
\end{tabular}


According to Table 4, among the four "dirty" regions of the Russian Federation, the Kemerovo region ranks last, but according to the level of environmental load, due to the limited territory, it is the first. As for the neighboring regions, here our region is in the leading position with a huge margin.

Table 4. Emissions of pollutants into the atmosphere from stationary sources in the four most "dirty" regions of Russia [4].

\begin{tabular}{|c|c|c|c|c|}
\hline \multirow{2}{*}{ Year } & \multicolumn{4}{|c|}{ Emissions of pollutants into the atmosphere from stationary sources } \\
\cline { 2 - 5 } & $\begin{array}{c}\text { Krasnoyarsk } \\
\text { Region }\end{array}$ & $\begin{array}{c}\text { Sverdlovsk } \\
\text { Region }\end{array}$ & $\begin{array}{c}\text { Tyumensk } \\
\text { Region }\end{array}$ & $\begin{array}{c}\text { Kemerovo } \\
\text { Region }\end{array}$ \\
\hline 1998 & 2636 & 1279 & 3716 & 893 \\
\hline 2002 & 2471 & 1221 & 3358 & 1240 \\
\hline 2006 & 2469 & 1249 & 4021 & 1311 \\
\hline 2010 & 2490 & 1169 & 3131 & 1410 \\
\hline 2014 & 2355 & 1021 & 2181 & 1331 \\
\hline 2015 & 2475 & 983 & 2145 & 1344 \\
\hline 2016 & 2363 & 906 & 2291 & 1349 \\
\hline
\end{tabular}

In Kemerovo region, there are now "anti-sustainable" trends in the dynamics of environmental intensity indicators, which is manifested in the increase of these indicators in many sectors. Certain indicators of environmental intensity in the fuel industry are constantly increasing. Land consumption and waste capacity in the coal industry was increased and the reason for this was the almost complete transition of coal enterprises to an open method of coal mining. At the same time, the level of environmental sustainability of the industry as a whole is quite stable, and the last 2-3 years even some decrease in some sectors can be traced. However, such dynamics can only be interpreted as evidence of a decrease in the relative (but not absolute) load on the natural environment, i.e. as a reduction in the load compared with the case of constant nature conservation. This means that a decrease in the environmental intensity of GRP can occur in a situation where only the relative load on the natural environment is reduced, and the absolute load, expressed by the indices of various pollutions in the calculation, for example, per unit of territory, is increasing (Table 5).

Table 5. Specific environmental load in the regions of the Russian Federation.

\begin{tabular}{|l|c|c|c|c|}
\hline \multirow{2}{*}{ Region } & \multicolumn{4}{|c|}{ Level of ecological load } \\
\cline { 2 - 5 } & $\begin{array}{c}\text { Emissions } \\
\text { per person, } \\
\mathbf{t} / \mathbf{h}\end{array}$ & $\begin{array}{c}\text { Emissions } \\
\text { per unit } \\
\text { area, } \mathbf{t} / \mathbf{~ k m}\end{array}$ & $\begin{array}{c}\text { Discharges } \\
\text { per unit area }\end{array}$ & $\begin{array}{c}\text { Formation of } \\
\text { hazardous waste } \\
\text { per unit area }\end{array}$ \\
\hline Tyumensk Region & 0.24 & 4 & 4.2 & 12 \\
\hline Kemerovo Region & 0.36 & 11 & 8.2 & 17 \\
\hline Novosibirsk Region & 0.04 & 0.9 & & 2 \\
\hline Tomsk Region & 0.08 & 2 & 0.3 & 3 \\
\hline Sverdlovsk Region & 0.29 & 6.7 & 9 & 11 \\
\hline Altai Region & 0.06 & 1.6 & 0.15 & 5 \\
\hline
\end{tabular}




\begin{tabular}{|c|c|c|c|c|}
\hline \multirow{2}{*}{$\begin{array}{c}\text { Region } \\
\text { Krasnoyarsk Region }\end{array}$} & 0.33 & 7.9 & 3.6 & 14 \\
\cline { 2 - 5 } & & & \multicolumn{4}{|c|}{ Level of ecological load } \\
\hline
\end{tabular}

Assessing the trends in the change in the indicators of environmental intensity, it should be noted that from the stand point of achieving economic stability, their dynamics can vary significantly. The energy intensity, intensity of emissions and discharges of pollutants should decrease.

A reflection of positive environmental and economical trends will be an increase in the renewal of fixed assets, the use of toxic waste, the area of protected natural areas. Positive dynamics for our economy in the above indicators can not be traced (Table 6). So, for example, there is a constant increase in depreciation of industrial fixed assets, despite the fact that investments in fixed assets increase annually. More than $80 \%$ of all investments go to overhaul the already obsolete equipment.

At the same time, it should be noted that the structure of investments in fixed assets by itself is ineffective, since most of the funds go to the extractive industry. The share of investment in fixed assets for environmental protection and rational use of natural resources is just over $1 \%$.

Obviously, in the future, for the next few decades, there will be no departure from the resource-resource type of the region's economy. The strategy of social and economic development of the region until 2025 is approved, according to which the growth rate of industrial production in comparison with 2005 will be $150-155 \%$, and coal production will increase by 1.7-2 times [5].

Table 6. The dynamics of depreciation of the fixed assets of industry and the level of investment in their recovery [6].

\begin{tabular}{|l|c|c|c|c|c|}
\hline \multicolumn{1}{|c|}{ Year } & $\mathbf{2 0 1 1}$ & $\mathbf{2 0 1 2}$ & $\mathbf{2 0 1 3}$ & $\mathbf{2 0 1 4}$ & $\mathbf{2 0 1 5}$ \\
\hline $\begin{array}{l}\text { Degree of depreciation of } \\
\text { fixed assets of industry (\%) }\end{array}$ & 43.7 & 43.6 & 43.8 & 43.4 & 46.8 \\
\hline Fuel & 45.4 & 42.1 & 42.4 & 44.7 & 41.8 \\
\hline Metallurgical & 55.6 & 55.5 & 56.3 & 57.1 & 53.4 \\
\hline $\begin{array}{l}\text { Investments in fixed assets } \\
\text { of industry (million rubles) }\end{array}$ & 214780 & 267812 & 217711 & 230951 & 162059 \\
\hline
\end{tabular}

\section{Results and discussion}

It should be taken into account that the development of the coal mining industry of Kuzbass is accompanied by an increase in emissions of controlled, so-called mine methane from 2005 to 2015 , methane emissions increased by 246.398 thousand tons, or $47.2 \%$. This is according to the official reporting on form 2 TP-Air.

According to the Institute of Coal and Coal Chemistry of the RAS, the extraction of one ton of coal is accompanied, on the whole, by the separation of 5 to $25 \mathrm{~m}^{3}$ of methane. Emissions of methane in mines are accountable. As for quarries, then, since methane is lighter than air, it immediately evaporates and the existing control methods can not be accounted for. However, there is no reason to believe that the mine and the mine, which work on the same gas-bearing strata, emit substantially different amounts of methane into the atmosphere. Hence, the annual supply of methane to the atmosphere can be estimated at 3 billion $\mathrm{m} 3$ or 1.6 million tons, which is comparable to the gross emission of all Kuzbass industry. 
Conversion of $\mathrm{HF}$ emissions into $\mathrm{CO}_{2}$ equivalent according to the formula specified in the "Procedure for centralized recording of documents on emissions and sinks of greenhouse gases by economic entities in the territory of the Russian Federation" approved by Order No. 40 by Roshydromet on March 23, 2001, gives the following results (Table 7).

Analysis of the data shows that carbon emissions into the atmosphere of the Kemerovo region are constantly increasing. Since 2012, carbon emissions have increased annually by an average of 90 thousand tons. Thus, the planned increase in production in the coal industry will entail a constant increase in the volume of $\mathrm{CO}_{2}$, with the same data remaining unchanged. The internationally accepted assessment of the damage to the environment caused by $\mathrm{CO}_{2}$ emissions defines it as $\$ 20 /$ ton. Thus, the average annual damage to the economy of the Kemerovo region from carbon dioxide emissions alone is approximately $\$$ 175 million, which is more than 10 billion rubles, or 1.2\% of GRP (according to 2015).

Table 7. Emissions of $\mathrm{CH}$ and $\mathrm{CO} 2$ (thousand tons / year).

\begin{tabular}{|l|c|c|c|c|c|c|c|c|c|c|}
\hline & \multicolumn{2}{|c|}{1990} & \multicolumn{2}{c|}{2000} & \multicolumn{2}{c|}{2010} & \multicolumn{2}{c|}{2012} & \multicolumn{2}{c|}{2015} \\
\cline { 2 - 11 } & $\mathbf{C H}$ & $\mathbf{C O}_{2}$ & $\mathbf{C H}$ & $\mathbf{C O}_{2}$ & $\mathbf{C H}$ & $\mathbf{C O}_{2}$ & $\mathbf{C H}$ & $\mathbf{C O}_{2}$ & $\mathbf{C H}$ & $\mathbf{C O}_{2}$ \\
\hline $\begin{array}{l}\text { Kemerovo } \\
\text { Region }\end{array}$ & 254.32 & 5165.3 & 276.22 & 5611.5 & 412.23 & 8656.8 & 416.99 & 8756.8 & 420.6 & 8832.7 \\
\hline $\begin{array}{l}\text { including } \\
\text { the coal } \\
\text { industry }\end{array}$ & 211.16 & 4452.4 & 235.23 & 4939.9 & 411.67 & 8645.2 & 416.4 & 8744.5 & 419.32 & 8805.9 \\
\hline
\end{tabular}

Activities to reduce greenhouse gases, along with the direct effects that it directly targets, have associated results, such as reducing emissions of conventional pollutants: $\mathrm{SO}_{2}$, NOx, TSP, heavy metals, etc., fuel economy, accelerating technological progress.

Activities to increase carbon sequestration by ecosystems are also multifunctional. The restoration of forests contributes to the protection of soils, the maintenance of the aquifer, and the protection of biological diversity. Sometimes these indirect or conjugate conclusions can be very significant. Properly taking into account these joint or related benefits will make it possible to more adequately represent the role of policies to reduce greenhouse gases and assess how aggressive this policy should be [7-10].

Today methane is disposed of at two coal-mining enterprises of Kuzbass - at the mine named after S.M. Kirov and the mine "Komsomolets" (part of JSC "SUEK-Kuzbass"). According to the annual report of SUEK, in 2015 the company recycled 7.51 million cubic meters of degassing methane (in five years - 30.16 million cubic meters), which is being squeezed onto the surface from the worked out area of the excavation sites. One million cubic meters was burned in the boiler room, 3.6 - in a flare unit, 2.9 - used to produce electricity for their needs at a mini-CHP. At the mine named after Kirov, there are three of them - one megawatt each. The economic effect of methane utilization from 2011 to 2015 was $\$ 5.2$ million.

Methane recovery was also tried at the enterprises of coal companies "Belon" and "Southern Kuzbass", but, according to available information, projects have not been implemented at present. In general, $80 \%$ of coal-mining enterprises for today have not moved to the solution of the "methane issue" yet.

It is necessary to ensure a radical change in the attitude of owners to the problems of ecology. Stabilization and even reduction of the negative impact on the environment should become an indispensable condition for increasing production at operating enterprises.

\section{Conclusion}


To solve environmental problems, a correction of the regional investment policy is needed, which is generally oriented towards the development of the region's economy and industry, however, investments in the region's economy become substandard, because more than $40 \%$ of investments go to the coal industry, exhausting natural capital that does not provide the creation of physical and reducing the quality of human capital.

The pace of financing and implementation of environmental protection does not allow to eliminate fully any cause of environmental problems, the main of which remain:

- morally and physically obsolete technologies and equipment in key branches of production by more than $45-58 \%$;

- insufficient equipment of sources of environmental pollution with gas-water treatment facilities and means for monitoring the state of the environment.

In our opinion, it is necessary to establish at the regional level a mechanism for financing the costs of protecting and restoring the natural environment, taking into account the specific damage to the territory, not only from the regional budget, but also at the level of a specific nature user, and strengthening the social responsibility of business.

\section{References}

1. Report on the state of the environment of the Kemerovo region in 2015 (AKO, Kemerovo, 2016)

2. S. N. Bobylev, M. Yu. Ksenofontov, R. A Perelet, A. P. Petrov, Macroeconomic and environment (Science, Moscow, 2004)

3. V. G. Samylina, Innovative Economics, 6:16, 150-158 (2016)

4. Rosstat, Macroeconomic Statistics, URL: http://www.gks.ru

5. N. N. Golofastova, V. G. Mikhailov, I. V. Seredyuk Economics and Innovation Management, 1, 66-75 (2017) DOI: 10.26730/2587-5574-2017-1-66-75Regions of Russia: socio-economic indicators. Official Edition (Rosstat-M., Moscow, 2016)

6. State of the natural environment of the Kemerovo Region. (Kemerovostat, Kemerovo, 2016)

7. A. V. Myaskov, S. M Popov, Economics and Innovation Management, 1, 16-24 (2018) DOI: $10.26730 / 2587-5574-2018-1-16-24$

8. A. N. Tokarev, Economics and Innovation Management, 1, 25-35 (2018) DOI: 10.26730/2587-5574-2018-1-25-35

9. A. B. Efremenkov, A. A. Khoreshok, S. A. Zhironkin, A. V. Myaskov, IOP Conf. Ser.: Earth Environ. Sci., 50:1, 012009 (2017)

10. M. Cehlár, J. Janočko, Z. Šimková, T. Pavlik, E3S Web of Conf., 15, 01019 (2017) 